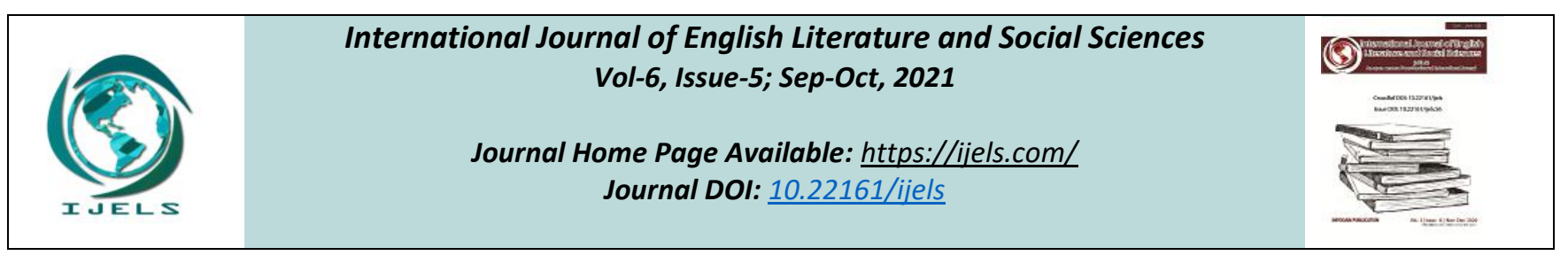

Peer-Reviewed Journal

\title{
Gandhi Myth in Kanthapura: Co-Mingling of Fact and Fiction
}

\author{
Najma Khatun
}

Assistant Teacher, Kazipara Haridas Vidyabhaban, West Bangal, India

Received: 18 Sep 2021; Received in revised form: 03 Oct 2021; Accepted: 09 Oct 2021; Available online: 16 Oct 2021

C2021 The Author(s). Published by Infogain Publication. This is an open access article under the CC BY license

(https://creativecommons.org/licenses/by/4.0/).

\begin{abstract}
Raja Rao, one of the trios of the Indo-Anglican novelists the other two are Mulk Raj Anand, R $K$ Narayan,had the power to intermingle or associate actual fact with fiction in order to give Indian Literature a new form of writing.This form is also found in $19^{\text {th }}$ century literature in the works of Jules Michelet- "The History de la Revolution" and Balzac's "Les Chouans". And this style of the fusion of factual and fictional is clearly evident in Raja Rao's first novel, Kanthapura (1938) where the reader can have the contemporary political event with the twist of mythical stories. Raja Rao consciously uses ancient mythological motifs as a technique of narration in the manner of modern English writers like T.S. Eliot, W.B. Yeats and others. Kanthapura is a novel dealing with the impact of the Gandhian freedom struggle movement on a remote south Indian village of that name. What happened in Kanthapura was also happened in India during the freedom struggle movement. The novel can be considereded as a Gandhi myth as Gandhi's influential personality is felt everywhere in the novel. Indeed, Gandhi does not appear personally but the plot revolves around his ideology. This work 'Gandhi myth in Kanthapura: Co-Mingling of fact and fiction' attempts to show how Kanthapura becomes an epitome of Gandhi myth through the association of fact and fiction.
\end{abstract}

Keywords - Intermingle, Mythological Motifs, Gandhian Freedom Struggle Movement, Epitome, Association.

\section{INTRODUCTION}

Mythological elements play an important role in shaping our lives. Myth is a traditional story specially the one concerning the early history of people or explaining a natural or social phenomenon involving supernatural beings or elements. It is sacred to all of us because it is religious and spiritual in explaining the universe.Raja Rao is very fond of mythical stories as in an interview with Shiva Niranjan, he says;

"I like to write like purana, I like the puranic conception, that is the only conception of the novel for me. I don't want to write like a foreign novelist. I am very much an Indian and the Indian form is the puranic form".

Raja Rao also says;

"I have written Puranas but not novels".
The present novel, Kanthapura is like a grandmother's tale which shows an authentic picture gallery with living human being. The novelist uses myth in two ways, Pan Indian Myth i.e.easily communicable and comprehensible such as Ramayana and Mahabharata and Localised Myth i.e. legendary history of a place, village (sthala- purna legendary history of a place) respectively (Mukherjee, 1974). Here in the novel, we have the juxtaposition of this two kind of myths.Raja Rao actually wanted to make us clear about the contemporary struggle movement of India led by Gandhi through his use of mythical technique.

In the history of India's struggle for independence the period 1920-1947 has been designed as the era of Gandhian Revolution as K R Iyengar termed the period between the two world wars as the Gandhi Age. Gandhi appeared as a legendary figure, a messiah, an incarnation of Rama of the Ramayana and Krishna of the Mahabharata 
who descended upon earth to kill the evils.It was a great attempt on the part of Gandhi, his ideals, personality and good jobs what Srinivas Iyengar (2005) wrote as Passive Resistance --- "It is a method of securing rights by personal suffering: it is the reverse of resistance by arms, it involves sacrifice of self" that influenced the imagination of many Indo-Anglican writer who wanted to express, to reflect or more frankly prove his ideas and ideal either directly or metaphorically in their witing. Having influenced by Gandhi's ideology Raja Rao creates the character of Moorthappa or Moorthy in Kanthapura. We can feel the presence of Gandhi clearly here.It is the story of a fictional south Indian village of that name during the period of Gandhi's political activism, the most vivid, graphic and realistic account of the freedom struggle movement in India and its impact on the masses.

Raja Rao actually makes us familiar with the Indian history of independence led by Gandhi through his comingling of fact and fiction. The fact is what happened in Kanthapura actually happened in India during the freedom struggle movement and fictions are the various mythological stories told in the novel. The narrative technique itself clears us about the artistic blending of mythical and the real. The story is told by Achakka, old and simple-hearted woman. Her unlettered imagination gives Raja Rao the opportunity to mingle god with men and to infuse his narrative with other worldliness. Achakka talks about Kenchamma,the local deity who protected the people of Kanthapura from the Demon and also about the legendary history of the village.The freedom struggle is presented here as a symbolic clash between gods and the demons which in turn symbolises a clash between the forces of good and evil i.e.,the goodness comes through Moorthy,a staunch Gandhi man who inspires the villagers to participate in the freedom struggle movement and the evils are the Britishers Through the narrative technique the novel becomes more a Gandhi epic than a piece of mere fiction.

Kanthapura is a perfect example of Gandhi Myth: Gandhi real, myth-fictional, the blending of past and present,of concrete and abstract and also long dead and living traditions.A writer must have dead poets in them with their present knowledge which will be reflected in their writing as well as a writer should have ancient knowledge while writing in contemporary environment(Eliot,1919). While writing "Kanthapura" Raja Rao was also aware of the ancient Mythological Stories along with his knowledge of contemporary freedom struggle movement in India. To the people of Kanthapura Gandhi's influence is seen as god, friend and mentor, guide and philosopher and Moorthy as Avatar. Moorthy is considered as the village Gandhi.He is the leader of the people of Kanthapura who got inspiration from Gandhi to free their homeland from the shackles of the British Rules. The various activities performed by Gandhi during the struggle movement are performed by Moorthy in the novel. Moorthy participates in the eradication of untouchability. He explains the economy of khadi and the importance of charka to the villagers and persuades them to take to spinning at their spare time. He says;

"Spinning is as purifying as praying" (Kanthapura3)

Moorthy gets charka from the village head office and distributes them to the people. Like Gandhi Moorthy also observes fast, organises picketing and satyagrahas, undergoes punishments and gets arrested and sent to jail.

Gandhi's ideology influenced not only Raja Rao but other Indian writers like Mulk Raj Anand (novels- Untouchable, Coolie), R K Narayan(Waiting for Mahatma) who tried their best to depict the various social evils and how it affects our daily lives. Gandhi was very fond of Harikatha since his childhood(My Experiments with Truth-autobiography of Gandhi) and here Harikatha is practiced in the village of kanthapura at first by Shastri who recited on Lord Shiva and Goddess Parvati and later by Jayaramachar who talked about Gandhi and his ideals.In his Harikathas, Jayaramachar talks about Goddess Parvati's struggled for Lord Shiva just like the country's struggle for freedom. Jayaram achar also influenced the people of Kanthapura to participate the movement led by Moorthy. Gandhi is the Large Mountain while Moorthy becomes the Small Mountain to the village. He is the village Gandhi.

Raja Rao very intellectually co-mingles factual and fictional, reality and illusion, the concrete and the abstract in Kanthapura and by doing so becomes an important figure in Indo - Anglican writing. Women played an important role in the freedom struggle movement of India and in Kanthapura women like Ratha, Narasimma, Rangamma also played vital role for the struggle movement led by Moorthy. Ratna led the Satyagrahis after Moorthy got arrested; she is the female counterpart of Moorthy.Not only Ratna but also Rangamma got inspiration from Gandhi's ideology. Rangamma inspired the Satyagrahis to face the oppression of the police and says that no one can hurt the immortal soul:

"No sister, the sword can split asunder the body, but never the soul" (Kanthapura)

Shiva is the three eyed and Swaraj too is three eyed: SelfPurification, Hindu Muslim unity and khaddar (Kanthapura 16).Gandhi is depicted as an emblem of Divine Power as well as Great Reality.The age-old faith of the villagers that Gods walk by lighted streets during the month of Kartik indicates that myth co-exist with 
Contemporary Reality. The recurrent reference to myth adds new dimension to the movement of struggle for freedom.

To conclude we may say that Gandhian Ideology influenced Raja Rao so much as Rao spent some months in Gandhi's ashram in 1942 that he creates his own voice, the character of Moorthy. Though the novel was written in France as Rao was in France during1928-1939 but he was always concerned for his homeland just like Gandhi with regard to making India free from foreign rule. Moorthy is none other than the replica of both Gandhian Ideology and his own self. Thus, Raja Rao deals with the theme of patriotism to make us aware about the nation's history, culture, religion particularly on the basis of Gandhian Ideology in Kanthapura. Besides being in foreign land Rao always wanted to make his homeland, a place just like Plato's Ideal world (Republic) or Thomas Moore's Utopian World (Utopia) devoid of social evils. Rao dreams of a world where no boundaries will be there i.e., social, religious, psychological economic as in 'Unto This Last' by John Ruskin which influenced Mahatma Gandhi so much that he published his own newspaper Indian Opinion where we have got the idea that everybody would get same salary. The blending of fact (Indian freedom struggle movement led by Gandhi) and fiction (mythological story telling) in Kanthapura gives Raja Rao the opportunity to place Kanthapura with the epics Ramayana or Mahabharata side by side and through this fusion kanthapura becomes a perfect example of Gandhi Myth.

\section{REFERENCES}

[1] Iyengar, KR Srinivasa. Indian writing in English(Revised Ed.). Sterling Publishers, New Delhi, 2005.

[2] Rao, Raja. "Kanthapura 24th Reprint.". Orient Paperbacks, New Delhi, 2008.

[3] Mukherjee, Meenakshi. The Twice Born Fiction: themes and techniques of the Indian novel in English. ArnoldHeinemann, 1974.

[4] Mittapalli, Rajesh,Piet Paolo. The Fiction of Raja Rao: Cultural Studies. Atlantic Publishers. New Delhi (2001).

[5] Vanisree, M and G. Mohana Charyulu. Mythological Motifs in Raja Rao's Kanthapura, International Journal Of English Language, Literature And Translation Studies (IJELR) 2. 3(2015), 332-334.

[6] Hossain, Bhat, Ishfaq. Use of Myth in Kanthapura: Paralleism Between Ramayana and Kanthapura, 2(1). (2017), 239-242

[7] Gandhi, Mahatma. Autobiography: The story of my experiments with truth. Courier Corporation, 1983.

[8] Eliot, Thomas Stearns. "Tradition and the individual talent." Perspecta 19 (1982): 36-42. 